\title{
RESEARCH PAPER \\ MANAGING PLAN IMPLEMENTATION IN THE ASANTE AKYEM SOUTH DISTRICT ASSEMBLY: CAPACITY ISSUES AND CHALLENGES
}

\author{
K. Frimpong \\ LIFEBOAT (NGO), P.O Box 261, Konongo, Asante Akyem North, Ashanti Region, Ghana. West \\ Email:frimten@hotmail.com
}

\begin{abstract}
:
After years of implementation of the new decentralised planning system in Ghana, problems of plan implementation still persist. This paper uses a case study approach to appraise the capacity of the Asante Akyem South District Assembly (AASDA) in managing the implementation of its development plans. Using questionnaires and Organisational Capacity Assessment Tool (OCAT), the paper examines the capacity of the district assembly to implement its plans in six areas. The extent of implementation of a medium term development plan (2002-2005) was also reviewed. Finally the paper draws on the capacity situation of the district assembly and concludes that the assembly requires capacity upgrading to leverage its full potential in grassroots development.
\end{abstract}

Keywords: Capacity, Plan Implementation, Management, District Assemblies

\section{INTRODUCTION}

Development literature is full of concerns that several blueprints meant to stimulate development in many developing countries had not entirely been successful in achieving the anticipated desired impacts. Ghana undoubtedly is a classic example as the incidence of poverty, diseases, squalor and many development challenges which these plans sought to address are still widespread. Also quite phenomenal is the growing spatial inequalities of development. The north-south divide epitomises spatial inequality in Ghana (Songsore, cited in Vanderpuye-Orgle, 2002). The rural-urban divide is also another dimension of the spatial inequality, and this has been attributed to the strategy of locating social services in the administrative centres for the benefit of the elite (Dickson, cited in Vanderpuye-Orgle, 2002).

Regardless of the efforts and resources sunk into the preparations of development plans in the past, many urban and rural dwellers are still confronted with a litany of development problems. Nevertheless, the universal acceptance of the utility of development plans as instruments for socio-economic transformation is not in dispute. As tools for development, plans give focus, direction, sense of imagination and vision to an entity or an administrative authority. The absence of plans may thus lead to untimely changes in focus, duplication of efforts and 


\section{Frimpong}

inconsistencies. Therefore without plans, actions become merely random activity, producing nothing but chaos (Goetz cited by Goel, 2003). Development plans are generally paper representations of precise and purposeful goals, objectives and programmes and projects of what organisations, local authorities and countries as a whole want to achieve over a period. They are therefore seen as structured documents of development proposals and policies covering an area or entity over a time with the overall aim of bringing about change with improvements.

Successive governments of Ghana have therefore embraced development plans as valuable tools for development regardless of their ideological inclinations as plans have become synonymous with every regime change. The question often asked however is what happened to all these plans? So although Ghana's carefullywrought development dossiers had good intentions, most of them have remained on the shelves, while needless efforts are spent on reinventing the wheel at greater cost.

Other plans also had their life span truncated through regime changes. An example is the Seven-Year Development Plan (1963-1970) whose implementation was abandoned after the coup of 1966. Consequently, countless numbers of programmes and projects were abandoned. In cutting the sod for the construction of the Bui Dam Project, Benjamin (2007) remarked, 'this newly packaged project is a revival of an Nkrumah idea that got scrapped during his 1966 overthrow', The many uncompleted projects scattered across the country, the state of dilapidation and the degree of disrepair of some of these uncompleted infrastructures are inconceivable, and only reflects and affirms the problem of plan implementation or the lack of progression between plans and implementation.

The challenges of centralisation including poor plan implementation records, thus underpinned a paradigm shift to decentralisation, which was touted as an indispensable panacea to the chal- lenges associated with the top-down approach. According Owusu and Afutu-Kottey (2010), decentralisation brings government closer to the ground both spatially and institutionally. Empower minority and vulnerable groups to be part of the development process (Kyei, 2008), and also improve the capacity of local councils to deliver services and responsive to the needs of the citizens (Manyak and Katono, 2010). However as agencies for implementation, district assemblies can effectively perform this onerous responsibility only if they possess the requisite plan implementation capacities. This paper therefore sought to ascertain the mismatch between provisions in plans and plan implementation at the district level by asking the following question: Does the Asante Akyem South District Assembly have the capacity to manage the implementation of its development plans?

\section{UNDERSTANDING CAPACITY AND PLAN IMPLEMENTATION MANAGE- MENT: THEORIES AND CONCEPTS}

It is noteworthy that the delineation of a district, provision of office accommodation, creation of administrative structures and legislative framework by themselves do not necessarily translate into rapid development of a local government area. To have a meaningful and equitable development therefore, district assemblies must have the appropriate capacities to deliver. What then is capacity? Diverse opinions have been expressed on what constitutes capacity. For the purposes of this paper, capacity shall be contextualised as "capacity for something". In the generic and ordinary usage, the term capacity connotes the ability or power to achieve something. According to (UNDP, 2006), capacity is "the ability of individuals, institutions and societies to perform functions, solve problems, set and achieve objectives in a sustainable manner", or the ability to perform appropriate tasks effectively, efficiently and sustainably (Hopkins, 1994). It also represents an organisation's ability to perform work (Yu-Lee, 2002), whereas OECD/DAC (as cited in UNDP, 2006) also sees capacity as the ability of people, or- 
ganisations and society as a whole to manage their affairs successfully.

From the viewpoints so far expressed on capacity, two main issues emerge. The first has to do with the individual or institution in question possessing the required capabilities. Possession of the ability to undertake specific functions is very important, because this makes the organization, individual or even a nation to be selfreliant in the discharge of its duties. The second issue of utmost concern is sustainability. Implying that, the ability to perform certain functions should not be ephemeral but must grow and even become better and stronger with the passage of time. There can therefore be no meaningful capacity if the two elements of ability and sustainability are missing.

Assessing the capacity of an organisation is therefore seen as "an analysis of current capacities, against desired future capacities" (UNDP, 2006), or an exercise undertaken to appraise the existing capacity of an individual or collective entity to perform key functions and deliver expected results" (UNDP, 2005). Altogether, capacity assessment obeys the simple planning principle that enjoins one to know what is available (situational analysis) before determining the normative. A fair disclosure of the existing strengths, weaknesses, opportunities and gaps are some of the expectations of capacity assessment exercise. Capacity assessment is therefore used to determine the additional capacity or improvements required to upgrade the workings of organisations to perform functions for which they were established. However as Hopkins (1994) has remarked, what continues to be a "missing link" is the capacity assessment methodology that provides realistic baseline data of what is the current state of affairs and what it will take to move from one point another. In summary, a capacity assessment exercise entails any rigorous analysis in an effort to know the true state and readiness of institutions to deliver.

Some typologies of capacity assessment meth- odologies include: The UNDP 'Default' Capacity Assessment Framework (UNDP, 2006), the Programme Approach modelled along the Harvard Framework (Hopkins, 1996) and Mckinsey Capacity Assessment GRID (n.d). This study however mostly adopted the UNDP assessment framework. Regardless of the method of choice, capacity assessment in general must be systematic, logical and multistage. The first stage involves identification and delineation of the organisation to be assessed as well as a clear statement of purpose. The second stage requires the assessor to conduct a fairly rigorous capacity assessment by first determining and using appropriate data collection instruments and collecting the relevant data. The final stage involves analysing the data collected. In the words of (Hopkins, 1996), this will produce salient issues and themes that identify capacity gaps or deficits which will require some improvements.

Plan implementation on the other hand, simply connotes getting the work done, and this involves a series of activities carried out in a well coordinated manner to move a plan into reality. In the lexicon of development planning, implementation is considered as a series of activities that happen after plans have been prepared. Implementation is therefore the bridge between plans and realties. However, as Conyers \& Hill (1984) point out, effective implementation is very demanding. The prerequisites of effective plan implementation have thus been summarised as follows: knowing what you want to do, having the required resources, ability to assemble, control and manage these resources, and communication with collaborating agencies (Barret and Fudge cited in Conyers and Hills, 1984). Let me also add that monitoring and evaluation are integral to successful plan implementation.

It is inferred from the foregoing that managing plan implementation entails appreciable dexterity in mobilising, organising and managing resources at the disposal of the implementing agency. These resources according to Conyers 


\section{Frimpong}

and Hills (1984) are finance, manpower and equipment. Perhaps, it is due to the crucial role of management that Kinsey (1987) informs us that even a poorly designed plan has a good chance of success in the hands of skilful managers. The capacity appraisal thus examines some elements of management namely: staffing, budgeting/finance, equipment, monitoring and evaluation, coordination and other institutional arrangements deployed for managing plan implementation by the Asante Akim South District Assembly (AASDA).

Several approaches in managing plan implementation exist. One of them is Implementation Management Systems (IMS) which incorporates a lot of measures and techniques. Examples of these techniques of plan implementation are: Project Breakdown Structure, Milestone chart, Gantt chart, and Network techniques. Others include array of reporting and monitoring procedures and finally strategies for coordination. There are two aspects of the IMS. These are the Programming and Implementation Management (PIM) and the "Operation Room System', (ORS) implemented in Kenya and Malaysia in the 1970s and 1950s respectively. See Conyers and Hills (1984) for further readings. The review of available literature has without doubt revealed the enormity and complexities involved in implementing a plan. The process requires resources (human, financial, equipment) in the right quantities and at the right time, as well as collaboration with relevant stakeholders.

\section{MATERIALS AND METHODS}

Documentary sources of data and background information for the study were obtained from books, Local Government publications and the internet. Budgets, trial balances and a medium term development plan (2002-2005) of the assembly were also scanned. Primary data were collected from Area/Town Councils and heads of selected decentralised departments. The District Coordinating Director (DCD), District Planning Officer (DPO), District Budget Analyst (DBA), Finance Officer and the District
Engineer were the key informants interviewed. These officials constitute the core adroit personnel very much knowledgeable in the operations of the assembly and possessed enough information in the specific areas of the investigations. The District Planning Coordinating Unit (DPCU) also formed one of the main units of analysis because of its peculiar role in plan preparation, implementation, and monitoring and evaluation.

Self-administered questionnaire and face-toface interviews were the main instruments used in collecting primary data. These were complemented by capacity self-assessment sheet using a modified Organisational Capacity Assessment Tool (OCAT). Data gathered were triangulated by means of multiple sources as well as using different data collection instruments. Data were also gathered through anecdotal and ocular means. Although information obtained through anecdotal and ocular means did not directly influence the outcome of the studies, it played invaluable roles and served as useful lenses in the probe for further information. Altogether, data collected for the study represented a good blend and balance of both quantitative and qualitative data and situated within the context of the study objectives.

\section{RESULTS AND DISCUSSION \\ Review of Implementation of 2002-2005 Me- dium Term Development Plan}

A review of the extent to which the assembly implemented its 2002-2005 Medium Term Development Plan (MTDP) revealed the following: Out of a total of 75 projects and programmes earmarked for implementation during the planned period, ten (i.e 13.3 percent) were never implemented. A total of 46 (61.3 percent) projects and programmes were completed within the planned period, while 19 (25.4 percent) were on-going. Of the 46 completed projects and programmes, 12 (26 percent) exceeded their targets by about 105.9 percent to 400 percent. For example instead of the set target of providing eleven school blocks, fifteen were actually provided. The reason was that the 
assembly received additional funding and equipment from sources such as Highly Indebted Poor Countries (HIPC) relief fund, Ghana Education Trust Fund (GETFUND), Village Infrastructure Programme (VIP) and from the Hunger Project, an NGO. The actual work done in all of the on-going projects was found to be on the average less than 50 percent. It also became clear that projects that were not implemented during the period under review were those requiring huge capital outlays. Examples included projects like completion of bungalow for district director of education, construction of a 150 bed hostel for third and second cycle schools, mortuary at the Juaso District Hospital, acquisition of X-ray equipment, and construction of a police station at Juaso. Implementation rate for non-physical projects was thus observed to be higher than in physical projects.

It is significant to note also that external revenue inflows which presumably were least anticipated and unbudgeted for rather became very crucial in meeting certain targets and in some cases exceeding the targets set. What then would have been the situation without these unexpected inflows? Largely, the underlying factor for the inability of the assembly to fully implement its plan was inadequate funding.

This is because in the assembly's own review of the 2002-2005 MTDP, lack of funding or inadequate funds was cited in as many as twenty-one times as the reason why certain projects and programmes were not completed or implemented at all. The assessment of the financial capacity of the assembly later on in the paper reinforces this viewpoint. One of the following could also be inferred from the foregoing: that either the plan was not realistic, overly ambitious targets were set relative to disposable resources, or that the plan was not based on a careful examination of the capacity of the assembly to fully implement it. The next sections thus discuss some of these areas/ variables of the district's capacity beginning with staffing.
Staff Strength, Competencies and Qualifications

Core staffing situation and technical capacity of the assembly (central administration) were also examined in terms of qualifications, staff development policies, incentives, attrition, and working experiences with district assemblies (DAs). The outcome is summarised in Table 1.

The staff audit showed that the district assembly was understaffed as key positions such as Deputy District Coordination Director (DCD), Assistant Planning Officer, Budget Officer and Town and Country Planning Officer were vacant. The AASDA also had no estate manager although the district's organisational structure made provision for such a position. As many as 40 vacancies existed for revenue collectors. Whilst some key officials had academic qualifications over and above the minimum requirements, several other key staff did not possess the preferable minimum academic qualifications. The reason was not the unavailability of such skills on the labour market, but rather the unattractiveness of the Ghanaian Civil Service. This is compounded by the unduly long time and bureaucracy involved in the recruitment processes.

Certainly, investments in training hold good promise for career development, increased earnings and a great source of staff motivation. However evidence gathered indicated that although the AASDA had a policy for staff training, little importance was attached to this policy in terms of budgetary allocations. The percentage shortfall between budgets and actual expenditures on staff training increasingly became wider over time. For example, the gap between estimates and actual amount spent on staff training was 5.9 percent in 2005. The figure however increased to 6.4 and 38.4 percent in 2005 and 2006 respectively. This in a way suggests that the AASDA placed less premium on staff training as it was also disclosed that about 58.8 percent of all training programmes for staff between 2002 and 2005 were never implemented. Staff transfers are done by the 
Table 1: Core staffing position of AASDA

\begin{tabular}{|c|c|c|c|c|c|c|}
\hline & $\begin{array}{l}\text { Required } \\
\text { Number }\end{array}$ & Qualification & $\begin{array}{l}\text { Existing } \\
\text { Number } \\
\text { present }\end{array}$ & $\begin{array}{l}\text { Existing } \\
\text { qualifica- } \\
\text { tions }\end{array}$ & $\begin{array}{l}\text { Working } \\
\text { Experi- } \\
\text { ence } \\
\text { with DAs }\end{array}$ & $\begin{array}{l}\text { No. of } \\
\text { years } \\
\text { with } \\
\text { AASDA }\end{array}$ \\
\hline DCD & 1 & $1^{\text {st }}$ degree & 1 & $\begin{array}{l}\text { BA,DPA, } \\
\text { CPA,CUM }\end{array}$ & 21years & 2years \\
\hline Deputy DCD & 2 & $1^{\text {st }}$ degree & 1 & BA, MBA & 2years & 2years \\
\hline $\begin{array}{l}\text { Dist. Planning Officer } \\
\text { (DPO) }\end{array}$ & 2 & $1^{\text {st }}$ degree & 1 & $\mathrm{BSc}, \mathrm{PGD}$ & 15 years & 2 years \\
\hline Asst. DPO. & 1 & $1^{\text {st }}$ degree & No staff & - & - & - \\
\hline Dist. Budget Analyst & 1 & $1^{\text {st }}$ degree & 1 & BA & 13years & 4years \\
\hline Budget Officer & 1 & $1^{\text {st }}$ degree & No staff & - & - & - \\
\hline $\begin{array}{l}\text { Dist. Finance Officer } \\
\text { (DFO) }\end{array}$ & 1 & $\begin{array}{l}1^{\text {st }} \text { degree } \\
\text { ACCA (final) }\end{array}$ & 1 & ACCAII & & 2years \\
\hline Asst. DFO & 1 & ACCAI & 1 & ACCAII & & 1year \\
\hline Dist. Engineer & 2 & BSc. Civil & 2 & HND & 7years & 4,2years \\
\hline Internal Auditors & 5 & $\begin{array}{l}\text { BSc. ACCA } \\
\text { I,II }\end{array}$ & 1 & ACCAII & 1year & 1year \\
\hline Revenue Superintendent & 1 & SSCE & 1 & MSLC & 31years & 19years \\
\hline $\begin{array}{l}\text { Town \& Country Plg. } \\
\text { Officer }\end{array}$ & 1 & $1^{\text {st }}$ degree & No staff & - & - & - \\
\hline
\end{tabular}

Source: Author's field survey, April 2008

Regional Coordinating Council in the regional capitals. Logical inferences suggest that the little and declining investments in staff training and development stems from the fact that staff who receive additional training may be transferred from the district after huge sums of funds have been expended on their training. It was also observed that the AASDA had no Memorandum of Understanding (MoU) with any training institution including the Institute of Local Government Studies (ILGS) for the regular training of its staff.

The investigations further revealed that although records of the AASDA's staff were properly kept, these records were not stored in electronic format, thus making retrieval of staff records especially training records very slow and difficult. Staff turnover rate was also identified to be high among the core staff, since at the time of the study, most key staff had been at the district for an average of 3.9 years (see column 7 of Table 1). In sum the AASDA did not have the full complements of its staff while training programmes were rarely organised for staff to improve upon their knowledge base and skills, to be abreast with current trends and modern techniques of managing plan implementation.

\section{Physical Resource Capacity for Plan Imple- mentation}

The presence or otherwise of logistics/ equipment considered essential for effective plan implementation and other administrative functions was also evaluated. This involved stocktaking of equipment available to the assembly compared to the required. The conditions of these equipment were also adequately captured. Table 2 presents the equipment standing of the ASSDA during the study.

Like staffing, shortfalls were registered in almost all the equipment assessed. Exception to this was noted in the case of Flip Charts and LCD Projector where the existing number par- 
Table 2: Equipment status of the AASDA

\begin{tabular}{lllll}
\hline $\begin{array}{l}\text { Types of } \\
\text { Equipment }\end{array}$ & $\begin{array}{l}\text { Number } \\
\text { Required }\end{array}$ & Number Existing & Backlog & $\begin{array}{l}\text { Condition of Existing } \\
\text { Equipment }\end{array}$ \\
\hline Vehicles & 10 & 8 & 2 & Good \\
Motor bikes & 6 & 2 & 4 & no comments \\
Computers & 18 & 9 & 9 & fairly good \\
Photocopiers & 4 & 2 & 2 & Unserviceable \\
Fax machines & 2 & 1 & 1 & Unserviceable \\
Telephones & 5 & 1 & 4 & Unserviceable \\
(fixed) & - & - & & not available \\
MIS & 2 & 2 & & Good \\
Flip charts & & & & \\
& & & & Good \\
Others: & & 1 & & \\
LCD (projector) & 1 & &
\end{tabular}

Source: Author's field survey, April 2008

alleled the required. In addition to the deficits, some of the equipment were unserviceable. The assembly had neither a maintenance plan nor a contractual arrangement with any company for routine maintenance of its equipment, albeit, budget is provided annually for maintenance. The consequence of not having a maintenance plan that is rigidly followed is that most equipment will have their life span unduly shortened. This lack of routine maintenance probably explained why one photocopier and the only fax machine in the assembly were not operational at the time of the investigation. Inadequate equipment also implied the few available would be overused which eventually could affect their efficiency and working life. In summary the AASDA had inadequate equipment while the few available were poorly maintained.

\section{Financial Resource Capacity for Plan Imple- mentation}

The AASDA obtained its revenue from various sources to implement its plan. The most predictable and stable source(s) of revenue to the assembly, and the trend and pattern of growth in revenues and expenditures are some of the highlights in the financial resource capacity analysis. On the whole, this section sought to determine the fiscal performance of the assembly during the period under consideration. Like many other DAs in the country, Internally Generated Revenue (IGF) and government grants in the form of the District Assemblies Common Fund (DACF) constituted the main sources of revenue to the AASDA. Others included donor funding like the European Union Micro Projects, allocations from the Ghana Education Trust Fund (GETFUND) and reliefs from Highly Indebted Poor Countries (HIPC) reserves. The study found that IGF contributed a small percentage to the district's total revenue. While grants formed an average of 90.1 percent of the assembly's revenue, IGF contributed only 9.9 percent over six years as shown in Figure 1.

Notably, the contribution of IGF to the assembly's total revenue was highly insignificant as the highest ever contribution was 15.9 percent recorded in year 2007. This may be attributed to the inability of the district assembly to mobilise enough revenue locally. Grants thus ranked highest when the contributions of individual revenue sources were considered. This was followed at a distant second by lands (3.4 percent), rates (2.4 percent), fees and fines (2.1 


\section{Frimpong}

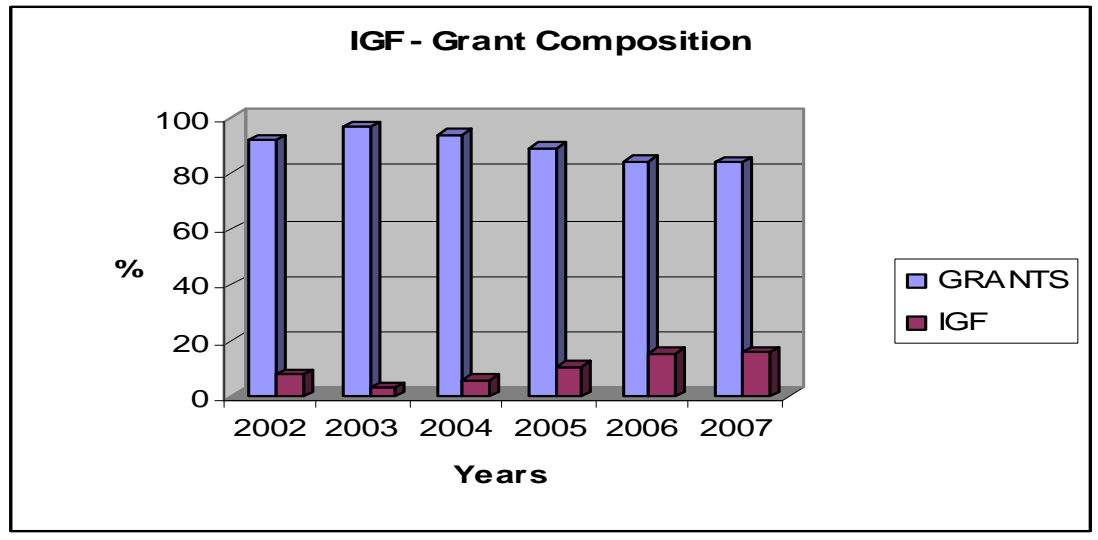

Fig. 1: Histogram of IGF and grants composition

percent), and license (1.4 percent) occupied third, fourth and fifth positions respectively. Revenue from investments ranked last contributing the least of 0.1 percent to the assembly's revenue.

Moreover, a time-lag between the due and actual dates for the release of the DACF - a major source of revenue to the assembly was observed. For instance it was noted that unpaid allocation for the third quarter of year 2002 was released in February 2007 (03-02-2007), while that of the fourth quarter for 2002 was released in July 2007 (25-07-2007). Similarly, the second quarter of the outstanding 2005 allocation was released in September (21-09-2005) instead of June, third quarter in November (14-11 -2005) instead of September, and the fourth quarter in March, 2006 (30-03-2006) instead of December, 2005. So apart from the third and fourth quarter arrears of year 2002 which took about five years to be paid, it was observed that averagely, it took two-and-half months to release the DACF after their due dates. The above amply supported the perspectives by many respondents that untimely release of funds is one of the problems confronting plan implementation in the district.

In spite of the untimely release of funds especially the DACF, the assembly also did not register any steady growth in revenue generation. On the average, the assembly's revenue grew at 9.5 percent annually between 2002 and 2007 peaking to about 153.8 percent increase occurring between 2002 and 2003. Afterwards, the assembly recorded negative growth between 2003 and 2005 with the highest drop of negative 120.7 percent occurring between 2006 and 2007. Figure 2 shows movements in revenue generation recorded by the assembly over the period.

The real value of all revenue accrued to the AASDA over the period under consideration was also estimated. The purpose was to determine the purchasing power and also allow for a meaningful comparison over the years by making adjustments for inflation. The average inflation rate over the period $2003-2007$ was 14.8 percent, implying that, the assembly could buy 14.8 percent less of the nominal value of all incomes received. The highest fall in the nominal value occurred in year 2003 where inflation was 23.3 percent as shown in Table 3. Also in times of delays in the release of funding, certainly project budget will be affected as more money (cost overruns) will be required to complete the same projects due to rising cost of materials occasioned by the inflation.

An aspect of the financial capacity assessment 


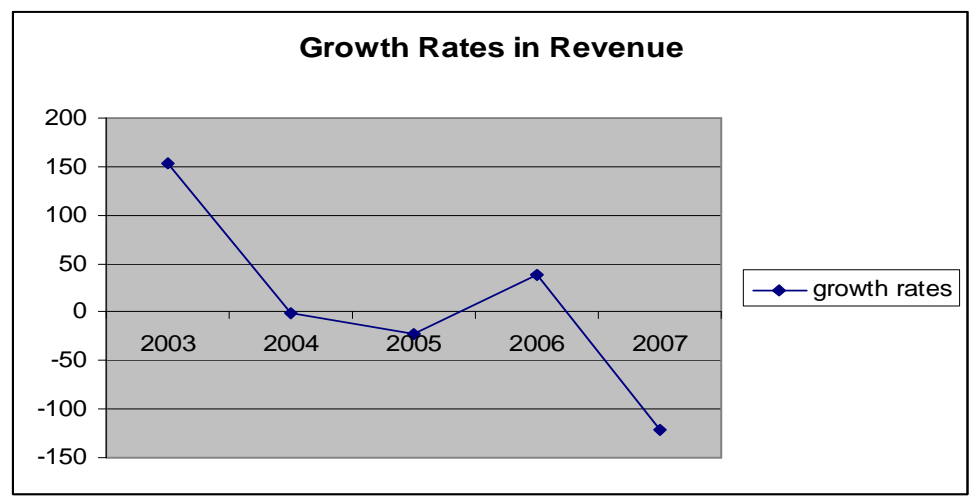

Fig. 2: Graph showing growth rates in revenue

of the AASDA was determination of the achievement rates or the Revenue Collection Index (RCI) in each of the revenue item/source. The purpose was to assess the reliability of the assembly's revenue forecast and indentify the revenue source(s) where more efforts need to be intensified. The RCI measures the actual revenue realised out of the total estimated (actual/estimates $\times 100$ ). The assembly achieved 93.1 percent of all revenue estimates in 2002 (aggregate of all revenue sources). This increased to 118.1 percent in 2003. This however took a nosedive recording a rate of 58.8 percent in 2005. The oscillatory trend continued with the rate plummeting to a low of 48.26 percent in the 2007 financial year. The annual rates achieved for all revenue sources and the cumulative rates of each revenue source over the period under consideration are presented in Table 4.
Stability of the various revenue sources was also assessed. This looked at the closeness or likelihood of achieving a set revenue target by simply calculating the coefficient of variation $(\mathrm{CV}=$ standard deviation/average $\times 100)$ of each of the revenue sources. From the computations, rent and grants emerged the most predictable sources of revenue to the assembly, while revenue from investments, lands, fines and fees were the most fluctuating and the least stable as shown in Table 5.

Rent emerged as the most stable source of revenue because it is made up of few items which are easily located and collected. Examples include market stores, stalls, lorry parks, and assembly's staff quarters. The position of fees \& fines as the most unstable or the source less likely to be achieved seem normal. This is because the number of criminal or unlawful cases

Table 3: Nominal versus real revenue (GH $)$

\begin{tabular}{lllllll}
\hline Years & $\mathbf{2 0 0 2}$ & $\mathbf{2 0 0 3}$ & $\mathbf{2 0 0 4}$ & $\mathbf{2 0 0 5}$ & $\mathbf{2 0 0 6}$ & $\mathbf{2 0 0 7}$ \\
\hline $\begin{array}{l}\text { Nominal } \\
\text { Value }\end{array}$ & 439980.1087 & 1116638.433 & 1107264.432 & 856475.0025 & 1181097.126 & 789169.64 \\
Deflator & 0.848 & 0.764 & 0.882 & 0.852 & 0.895 & 0.8725 \\
$\begin{array}{l}\text { Real } \\
\text { Value }\end{array}$ & 373103.1322 & 853111.7632 & 976607.2288 & 729716.7021 & 1057081.927 & 688550.511 \\
\hline
\end{tabular}


Table 4: Achievement rates for revenue sources

\begin{tabular}{lllllllll}
\hline $\begin{array}{l}\text { Year/ } \\
\text { Description }\end{array}$ & $\mathbf{2 0 0 2}(\boldsymbol{\%})$ & $\mathbf{2 0 0 3}(\boldsymbol{\%})$ & $\mathbf{2 0 0 4}(\boldsymbol{\%})$ & $\mathbf{2 0 0 5}(\boldsymbol{\%})$ & $\mathbf{2 0 0 6}(\boldsymbol{\%})$ & $\mathbf{2 0 0 7}(\boldsymbol{\%})$ & $\begin{array}{l}\text { Total for } \\
\text { 6yrs }\end{array}$ & Rank \\
\hline Lands & 253.36 & 136.3 & 173.2 & 84.0 & 333.6 & 43.9 & 1024.36 & $1^{\text {st }}$ \\
Miscellaneous & 120.81 & 26.3 & 257.5 & 53.7 & 53.3 & 310.9 & 822.51 & $2^{\text {nd }}$ \\
Rates & 101.1 & 77.9 & 77.5 & 72.4 & 202.8 & 85.5 & 617.2 & $3^{\text {rd }}$ \\
Fees \& Fines & 127.42 & 84.6 & 117.3 & 90.3 & 92.9 & 76.9 & 589.42 & $4^{\text {th }}$ \\
Licences & 95.4 & 89.0 & 116.4 & 59.3 & 55.1 & 126.3 & 541.5 & $5^{\text {th }}$ \\
Grants & 90.9 & 119.5 & 77.6 & 57.1 & 107.9 & 45.2 & 498.2 & $6^{\text {th }}$ \\
Rent & 62.5 & 66.8 & 67.8 & 62.1 & 74.9 & 76.8 & 410.9 & $7^{\text {th }}$ \\
Investment & 0.0 & 0.0 & 55.2 & 32.8 & 72.9 & 22.2 & 183.1 & $8^{\text {th }}$ \\
Total & $\mathbf{9 3 . 1}$ & $\mathbf{1 1 8 . 1}$ & $\mathbf{7 9 . 3}$ & $\mathbf{5 8 . 8}$ & $\mathbf{1 4 4 . 7}$ & $\mathbf{4 8 . 3}$ & & \\
\hline
\end{tabular}

Source: Derived from AASDA's Trial Balance, April 2008

Table 5: Stability of sources of revenue to AASDA (GHe)

\begin{tabular}{lllll}
\hline Revenue & Mean & Standard Deviation & $\begin{array}{l}\text { Coefficient of } \\
\text { Variation }\end{array}$ & Rank \\
\hline Rent & 24731.4259 & 816.28195 & 3.3 & $1^{\text {st }}$ \\
Grants & 877161.4894 & 304973.6895 & 34.8 & $2^{\text {nd }}$ \\
License & 10389.71 & 6591.83869 & 63.4 & $3^{\text {rd }}$ \\
Rates & 18829.9684 & 15826.56925 & 84.0 & $4^{\text {th }}$ \\
Miscellaneous & 2198.02141 & 2080.28393 & 94.6 & $5^{\text {th }}$ \\
Investments & 728.35375 & 743.98902 & 102.1 & $6^{\text {th }}$ \\
Lands & 26587.8 & 29498.09298 & 110.9 & $7^{\text {th }}$ \\
Fees \& fines & 40717.065 & 72725.25157 & 178.6 & 8 th \\
\hline
\end{tabular}

Source: Derived from AASDA's Trial Balance, April 2008

likely to occur in a financial year and the quantum of fines each will attract can be extremely difficult to estimate in practice. Overall, the financial capacity situation of the AASDA can fittingly be described as inadequate, over dependent on one source, and instability in revenue generation. These have implications on the ability of the assembly to fully implement its development plans. First and foremost, it would be difficult for the assembly to satisfactorily rely on its revenue projections for any realistic budgeting due to the downwards and upwards spiral in revenue sources. The erratic revenue inflows observed may be attributed to the inappropriateness of the projections techniques used in arriving at estimates.

Weaknesses in resource mobilisation capacity of the AASDA can also not be ignored. Although the assembly had a database on rateable items compiled in December 2005, this was yet to be updated at the time of the study. This raises legitimate concerns on how the assembly arrived at its revenue estimates before the database on rateable items was compiled. How accurate was the database? Could the nonupdated rateable database influence the assembly's revenue forecast? Again, the practice where revenue forecast for an ensuing year is based on actual extracted from the trial balance 
of the previous year, may not give the true potential of the assembly to raise revenue if the figures in the trial balance were themselves underestimated or inaccurate in the first place.

Besides the probable forecasting difficulties, the assembly's revenue collection was also encumbered by other problems like shortage of revenue collectors. Of the 83 revenue collectors (commissioned) the assembly required, it had only 40 leaving a backlog of 43 . Other problems affecting revenue mobilisation capacity of the assembly included: inadequate tax education, weak supervision, endemic poverty, high unemployment, improper management of the assembly's investments, and the numerous entry and exit points to the district which potential taxpayers can use to avoid paying levies. So apart from the sole reliance on grants undermining the fiscal independence of the assembly, the excessive reliance limits discretionary powers of the assembly as such grants tend to be either sector or project specific and are often accompanied by conditions.

Monitoring and Evaluation Capacity and Plan Implementation

The "nerve centre" for tracking the implementation of the assembly's plan is the District Planning Coordination Unit (DPCU). The unit monitors and evaluates the implementation of the district's plan and also coordinates the activities of all the decentralised departments related to implementing the plan. However it was revealed that the DPCU was under resourced, although it had the full complement of its membership. The unit received no budgetary allocations for monitoring, had no vehicle designated for monitoring activities, and the monitoring team also had no monitoring plan and timetable. The absence of a database capable of tracking and generating timely monitoring reports could affect plan implementation, because contractors could take advantage of the laxities in monitoring and evaluation and poor supervision to produce shoddy works. The lack of monitoring and evaluation system may also partly account for failure of contractors to meet significant benchmarks in project execution.

Assessment of five Area and two Town Councils in the district also uncovered a number of deep seated challenges militating against the functioning of the sub-district structures. These challenges in no small measure affected cooperation by the Councils in managing the implementation of the district's development plan. The challenges included inadequate office space, lack of basic office equipment and permanent staff. The Town and Area councils also had no bank accounts into which 50 percent of revenues collected from the area together with other funding sources such as special development funds are supposed to be deposited. Failure to open bank accounts thus contravened paragraph (42) and (43) of the legislative instrument (LI 1614) of 1995. Consequently the councils had no access to funding to cover even administrative expenses. Complaints of delays and sometimes non-payment of three Ghana cedis (GHф3.00) sitting allowance, travelling \& transport expenses and cost of refreshments for attending council meetings echoed in all the councils visited. None of the seven Town and Area councils studied had an action plan covering the development of their respective jurisdictions as required.

To sum it up the operational efficiency of the sub-district structures was identified to be weak. As a result the Town and the Area Councils played no role in managing plan implementation, and monitoring and evaluation of projects in their territories. Neither were they informed of contracts awarded for projects that were to be executed in their respective areas.

The continued existence of these challenges in no doubt undermined the very purpose and significance of district sub-structures which among others include citizenry participation and monitoring of plan implementation. Although all the seven councils visited had duly been inaugurated for the second time with majority of the old members retained, they were practically non-functional. 


\section{Frimpong}

\section{Stakeholder Collaboration in Managing Plan Implementation}

Stakeholder collaboration in managing plan implementation in the district was also investigated. Representations at committee meetings, submission of inputs for plan preparations, collection and collation of data, community animation and membership of the DPCU were some of the ways through which decentralised departments were involved in plan preparation and implementation. Further interrogations however disclosed that many of the decentralised departments never had copies of the 20022005 MTDP, let alone knowing their expected roles in its implementation. Meanwhile other decentralised departments like Education, Agriculture and Health had their own sectoral plans aside the district's MTDP which is supposed to be the composite blueprint to guide the development of the entire district over a period.

\section{CONCLUSION}

The study set out to appraise the capacity of the AASDA in managing the implementation of its development plan using the 2002-2005 MTDP of the assembly as the point of reference. The study revealed significant weaknesses in the capacity of the assembly in managing the implementation of its development plans. This was manifested in almost all the variables examined. Prominent among them was the DPCU which undoubtedly is the hub of coordination, monitoring and managing the assembly's plan implementation processes. The DPCU should be performing activities akin to the 'operating room system' in Kenya where meetings on progress monitoring and the status of plan implementation are displayed and on-the-spot decisions are taken. However the DPCU was noted to be dormant as members rarely met.

Central to all the capacity issues confronting the assembly was finance as the assembly overly depended on one revenue source, the DACF. As a result a lot of projects and programmes in the assembly's $2002-2005$ development plan which involved huge capital outlay were delayed or not implemented at all as indicated already. The AASDA certainly requires capacity upgrading and the following are suggested: development of human resource, retooling of the logistics and equipment capacity, and strengthening the DPCU's monitoring and evaluation activities. Other recommendations include: enhancing coordination between central administration and all decentralised departments, improving resources mobilisation, operationalising sub-district structures (Town/ Area Councils), and lastly boosting leadership capacity by organising training programmes in leadership and governance for district chief executives and coordinating directors. The general expectations are that with good and proactive leadership, the assembly is more likely to surmount most of the plan implementation hurdles confronting it, and to achieve remarkable development at the local level in line with the vision of decentralisation and local government. As Sakyi et al (2011) have remarked, decentralisation has profound impacts and implications for the management, governance and delivery of public services. For these reason, the capacities of district assemblies must be enhanced to make them functional and relevant. Though data for the study was geographically limited to the administrative region of the AASDA, it is hoped that the recommendations thereon will have useful applications in other jurisdictions.

\section{REFERENCES}

Benjamin, C. (2007). \$25M seed money for Bui city. Retrieved June 30, 2008, from http//:www.thestatemanonline.com/pages/ news_detail.php? section $=2 \&$ ne wsid $=2607$

Conyers, D. and Hills, P. (1984). Introduction to development planning in the third world. John Willey \& Sons Ltd., New York.

Goel, S. L. (2003). Public administration theory and practice. New Delhi: Deep \& Deep Publications PVT Ltd.

Hopkins, T. J. (1994). Handbook on capacity 
Managing Plan Implementation... 129

assessment methodologies: An analytical review. Retrieved May 15, 2007, from http://mirror.undp.org.magnet/CAPMET

Hopkins, T. J. (1996). Capacity assessment guidelines and the programme approach: Assessment levels and methods. Retrieved January 7, 2008, from http:// www.mirror.undp.org.magnet/Docs/cap/ CAPLEV.html.

Kinsey, B. H. (1987). Agribusiness and rural enterprise. New York: Croom Helm Ltd.

Kyei, P. O. (2008). Decentralisation and poverty alleviation in rural Ghana: Perspectives from district elites and voices of the poor. Bulleting of Ghana Geographical Association, Special edn. (24). pp. 5-25.

Manyak, T. G. and Katono, I. W. (2010). Decentralization and conflict in Uganda: governance adrift. African Studies Quarterly, 11(4):1-24.

Mckinsey (n.d). Appendix: Capacity assessment grid. Retrieved May 15, 2007, from http://vppartres.org//earing/reoirts/ capacity/assessment pdf.

Owusu, G. and Afutu-Kotey, R. L. (2010). Poor urban communities and municipal interface in Ghana: a case study of Accra and Sekondi-Takoradi Metropolis. African Studies Quarterly, 12(1): 1-16.

Sakyi, E. K., Azunu, R. and Bawole, J. N. (2011). Does decentralisation lead to improvement in planning of health services? Findings from six district health administrations in Ghana. Journal of Local Government Studies, 3(1): 1-30.

UNDP (2005). Measuring Capacities: An illustrative catalogue to benchmarks and indicators. Retrieved May 13, 2007, from http://www4.worldbank.org/afr/ssatp/ Resources/HTML/Gender-RG

UNDP (2006). Capacity assessment practice note. Retrieved May 13, 2007, from w w w . c a p a c i t y . u n d p.org / index.cfmconference-2002-4/conference2002-4-p

Vanderpuye-Orgle, J. (2002). Spatial Inequality and Polarization in Ghana, 1987-99. Retrieved April 30, 2008, from http://62.237.131.23/conference/workingpapers/wp9crawford. Pdf

Yu-Lee, R. T. (2002). Essentials of capacity management. New York: John Willey and Sons, Inc 